\title{
A Simple Metallothionein-Based Biosensor for Enhanced Detection of Arsenic and Mercury
}

\author{
Gordon W. Irvine ${ }^{1}$, Swee Ngin Tan ${ }^{2}$ and Martin J. Stillman ${ }^{1, *}$ \\ 1 Department of Chemistry, The University of Western Ontario, 1151 Richmond St, London, \\ ON N6A 5b7 Canada; girvine@uwo.ca \\ 2 Natural Sciences and Science Education Academic Group, Nanyang Technological University, \\ 1 Nanyang Walk, 637616 Singapore, Singapore; sweengin.tan@nie.edu.sg \\ * Correspondence: stillman@uwo.ca; Tel.: +1-519-661-3821
}

Academic Editor: Jeff D. Newman

Received: 18 January 2017; Accepted: 10 March 2017; Published: 13 March 2017

\begin{abstract}
Metallothioneins (MTs) are a family of cysteine-rich proteins whose biological roles include the regulation of essential metal ions and protection against the harmful effects of toxic metals. Due to its high affinity for many toxic, soft metals, recombinant human MT isoform 1a was incorporated into an electrochemical-based biosensor for the detection of $\mathrm{As}^{3+}$ and $\mathrm{Hg}^{2+}$. A simple design was chosen to maximize its potential in environmental monitoring and MT was physically adsorbed onto paper discs placed on screen-printed carbon electrodes (SPCEs). This system was tested with concentrations of arsenic and mercury typical of contaminated water sources ranging from 5 to $1000 \mathrm{ppb}$. The analytical performance of the MT-adsorbed paper discs on SPCEs demonstrated a greater than three-fold signal enhancement and a lower detection limit compared to blank SPCEs, $13 \mathrm{ppb}$ for $\mathrm{As}^{3+}$ and $45 \mathrm{ppb}$ for $\mathrm{Hg}^{2+}$. While not being as low as some of the recommended drinking water limits, the sensitivity of the simple MT-biosensor would be potentially useful in monitoring of areas of concern with a known contamination problem. This paper describes the ability of the metal binding protein metallothionein to enhance the effectiveness of a simple, low-cost electrochemical sensor.
\end{abstract}

Keywords: paper-based biosensor; metallothionein; arsenic; mercury; green chemistry; screen-printed electrode

\section{Introduction}

Toxic metals are found naturally in the earth's crust at a very wide range of concentrations and are present in many environments. The inherent toxicity of these metals and their bioavailability influence the extent to which they pose problems for human health as well as plant and animal life. Two species with significant effects on human health are $\mathrm{As}^{3+}$ and $\mathrm{Hg}^{2+}[1,2]$. Mercury contamination, which has been well documented in Japan, as well as in other countries including Canada, has caused thousands of cases of Minamata disease [3]. Clearly, contamination from industry, agriculture and natural deposition must be monitored in a cost-effective and rapid method to prevent future cases [4]. $\mathrm{Hg}^{2+}$ is the most common speciation of mercury in aquatic systems owing to its biotransformation into an organic species [5]. Metallothionein (MT) has been shown to bind mercury with a high affinity and form stable complexes with a variety of species [6-9]. However, MT does not bind specifically to any one metal due to its fluxional nature and lack of defined binding sites that would discriminate against certain metal co-factors [10,11].

Arsenic, in particular $\mathrm{As}^{3+}$, is present at chronic levels in drinking water in many parts of the world but is not evenly distributed among sources [12]. Therefore, detection and quantification of arsenic in potable water and even water used for irrigation that can bioaccumulate in crops, is vital in assessing the security of various water sources $[13,14]$. 
Populations that are affected by significant arsenic contamination of their water supply tend to be poor and have limited access to expensive and centrally located testing facilities [15,16]. A cheap, portable, reliable and easy-to-use method to detect arsenic would help in monitoring contamination levels in poor, rural areas of South and Southeast Asia. The method must have a low detection limit due to the high toxicity of arsenic and mercury. Even low concentrations $(<50 \mathrm{ppb})$ of arsenic can have serious chronic effects $[17,18]$. Biosensors are a broad category of sensors based on biological materials that may meet these criteria of being cheap, portable and reliable.

Biosensors containing DNA, enzymes and metal-binding proteins are promising tools with which to obtain real-time, in-situ data for heavy metal contamination $[19,20]$. MTs are a family of cysteine-rich, metal-binding proteins that bind soft metals like mercury with a particularly high affinity [21-23]. $\mathrm{Hg}^{2+}$ has been shown to have higher affinity for MTs than other Hg-species [24,25].

At low $\mathrm{pH}, \mathrm{MTs}$ are able to bind strongly to $\mathrm{As}^{3+}$ although the reaction is slower than with native metals (zinc or copper) at neutral pH [7,26,27]. Cd-MT and Zn-MT demetalate below pH 3.5 [28] leaving the metal-free apo-MT available for the coordination of arsenic species [29]. The unique properties of MT make it an excellent candidate for increasing the sensitivity of electrochemical sensors, and efforts have been made to create MT-modified electrodes for metal sensing [30-33]. The success of many of these devices is limited due to the time consuming preparation and expense required for other essential components, such as MT-specific antibodies [34] or reducing agents [35]. In this study, our goal was to develop a low-cost, environmentally friendly biosensor using MT adsorbed onto paper discs and placed on screen printed carbon electrodes (SPCEs) for the detection of arsenic and mercury.

\section{Materials and Methods}

\subsection{Reagents and Instrumentation}

All reagents used were of analytical grade. Electrochemical characterizations and measurements were performed using a four-channel system (eDAQ QuadStat, e-Corder 8 and Echem software, eDAQ Europe, Warsaw, Poland). SPCEs (DRP-110) and the boxed connector for SPEs (DRP-DSC) were purchased from DropSens (Asturias, Spain). The working electrode was carbon while the reference and counter electrodes were $\mathrm{Ag} / \mathrm{AgCl}$ and a carbon ring, respectively. Circular paper discs were cut from Grade 1 filter paper (Whatman Asia Pacific Pte Ltd., Singapore). Standard solutions of $1000 \mathrm{ppm}$ $\mathrm{As}^{3+}$ and $\mathrm{Hg}^{2+}$ were diluted with $18 \mathrm{M} \Omega$ ultrapure water obtained from a Millipore Alpha-Q water system (Bedford, MA, USA) to final concentrations ranging from $1 \mathrm{ppm}$ to $5 \mathrm{ppb}$. Data were plotted on Microsoft Excel and refined using ORIGIN (Northhampton, MA, USA).

\subsection{Recombinant Protein Preparation}

Recombinant human metallothionein 1a (MGKAAAACSC ATGGSCTCTG SCKCKECKCN SCKKCC SCCPMSCAKC AQGCVCKGAS EKCSCCK KAA AA) was expressed with an S-tag in BL21 E. coli cells, as described in detail elsewhere [36]. In brief, cells containing the plasmid for the full protein $(\beta \alpha$-MT1a) were plated on to growth media containing kanamycin from a stock culture stored at $-80{ }^{\circ} \mathrm{C}$ and grown for $16 \mathrm{~h}$ at $37^{\circ} \mathrm{C}$. The grown cells were then inoculated into $4 \times 1 \mathrm{~L}$ broth cultures enriched with $50 \mu \mathrm{L}$ of $1 \mathrm{M}$ cadmium sulfate and incubated in a shaker for $4 \mathrm{~h}$ until the $\mathrm{OD}_{600}$ absorbance was 0.8 . Isopropyl $\beta$-D-1-thiogalactopyranoside (IPTG) was then added to induce expression of MT and 30 min later $150 \mu \mathrm{L}$ of $1 \mathrm{M}$ cadmium sulfate solution was added to the broth. The cells were collected $3.5 \mathrm{~h}$ after induction, centrifuged and stored at $-80^{\circ} \mathrm{C}$.

The recombinant cells were lysed using a cell disruptor (Constant Systems, Daventry, UK) shot at $20 \mathrm{k}$ psi. From there, the cell lysate was centrifuged for $1 \mathrm{~h}$ to pellet out cellular debris. The supernatant was filtered and loaded on to a GE healthcare SP ion exchange column with a total volume of $10 \mathrm{~mL}$. The columns were washed with pH 7.4 $10 \mathrm{mM}$ Tris(tris-hydroxymethyl-aminomethane) buffer for approximately $2 \mathrm{~h}$ to remove loosely bound proteins and other organic compounds. MT was eluted 
using an increasing gradient of $1 \mathrm{M} \mathrm{NaCl}+10 \mathrm{mM}$ Tris buffer at $\mathrm{pH}$ 7.4. The eluted MT was concentrated down to $<20 \mathrm{~mL}$ and lyophilized for storage and transport.

The lyophilized MT was reconstituted in $10 \mathrm{mM}$ ammonium formate buffer and buffer exchanged to remove excess salt. The MT solution was checked for oxidation using UV-Vis spectroscopy and ESI mass spectrometry to ensure the lyophilisation process did not cause oxidation of the MT thiols or loss of bound metals.

\subsection{Disc Preparation and Electrochemical Measurements}

Filter paper was cut into discs of approximately $8 \mathrm{~mm}$ using a hole puncher and a series of $20 \mu \mathrm{L}$ aliquots of reconstituted MT solutions were added to the discs to determine the optical concentration. The discs were kept in the fridge and allowed to dry under nitrogen to prevent oxidation. Once dry, the discs were placed on a DropSens electrode. The integration of the protein laden disc and SPCE has been described in detail elsewhere [37]. For the $\mathrm{Hg}^{2+}$ experiments measurements were taken with an incubation time of $2 \mathrm{~min}$ to allow for equilibration. While the reaction of apo-MT with mercury is rapid, the equilibration time is needed to allow for displacement of the $\mathrm{Zn} / \mathrm{Cd}$ bound to the protein on the paper disc.

For the $\mathrm{As}^{3+}$ experiments, $\mathrm{HCl}$ was added to the metal solutions to adjust the $\mathrm{pH}$ to 2.0. This was done to remove $\mathrm{Zn}^{2+}$ and $\mathrm{Cd}^{2+}$ still bound to MT adsorbed onto the paper disc. The equilibration time was longer, up to $30 \mathrm{~min}$ to allow for complete reaction as the kinetics of $\mathrm{As}^{3+}-\mathrm{MT}$ binding is known to be slow at room temperature [26].

Anodic stripping voltammetry (ASV) measurement parameters for both metal detection experiments were as follows: deposition potential $-350 \mathrm{mV}$; deposition time $150 \mathrm{~s}$; scanning range between -0.2 and $+0.3 \mathrm{~V}$; scanning rate $100 \mathrm{mV} / \mathrm{s}$; step $\mathrm{W} 20 \mathrm{~ms}$; step $\mathrm{H} 2 \mathrm{mV}$; eChem stripping linear mode.

\section{Results and Discussion}

The quality of the MT protein adsorbed on to the paper discs was checked first by ESI-MS prior to and after lyophilization to ensure purity. The protein was examined again prior to disc preparation by far UV absorption spectroscopy to monitor for oxidation of the thiols. UV spectroscopy is a fast, non-destructive technique for determining MT quality and concentration. The ligand-to-metal charge transfer (LMCT) absorption at $250 \mathrm{~nm}$ was used to calculate protein concentration. For use in the biosensor, it was crucial that there was little $(<0.15 \mathrm{abs})$ absorbance at $280 \mathrm{~nm}$ which would indicate the presence of oxidized thiols (Figure 1).

In the preparation of the MT-loaded discs, it was determined that solutions of $40 \mu \mathrm{M}$ gave the best signal response (Figure 2). Adsorption of additional aliquots of MT solution did not increase the signal response significantly, nor did the addition of higher concentrations of MT. This addition of $40 \mu \mathrm{M}$ concentration of MT to the paper discs results in approximately $8 \mu \mathrm{g}$ of protein being loaded in total. It should be noted that MT contains 20 cysteiene residues and is stored bound to $\mathrm{Cd}^{2+}$ so the thiol and $\mathrm{Cd}^{2+}$ concentration loaded on to the disc is 20 and 7 times larger, respectively. 


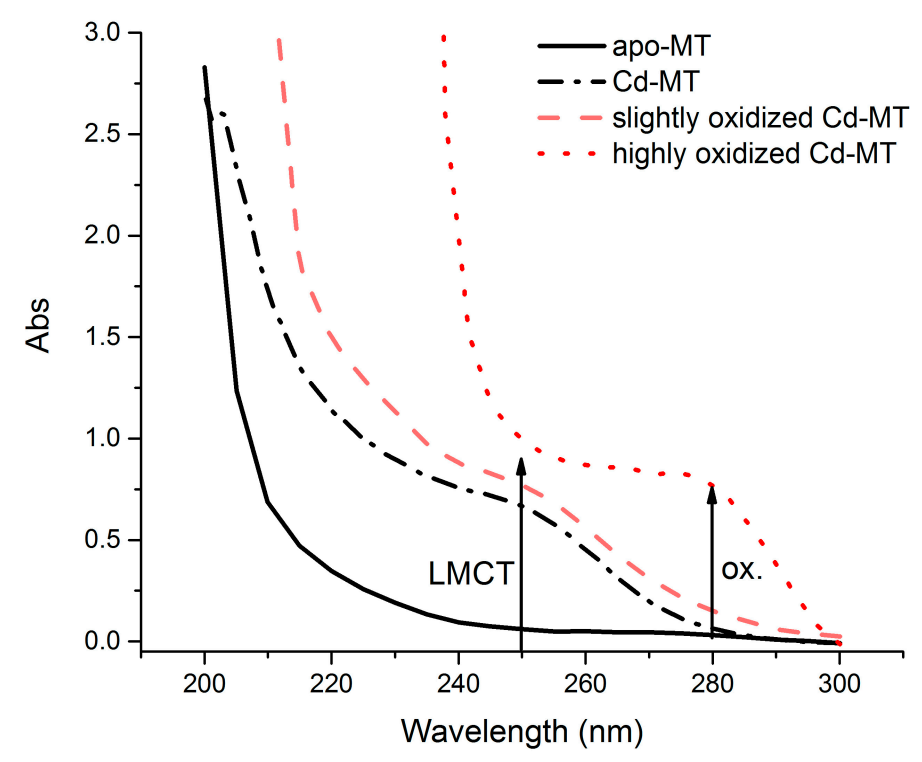

Figure 1. Far UV absorption spectra of metallothionein (MT) used to monitor oxidation of thiols. Apo-MT (solid black line), Cd-MT (dashed black line) are both fully reduced with no thiol oxidation. Aerated MT solutions are shown to illustrate the oxidation: minimal oxidation (dashed pink line) and significant oxidation (dotted red line). The ligand-to-metal charge transfer (LMCT) band and the oxidized thiol absorbance are highlighted with arrows.

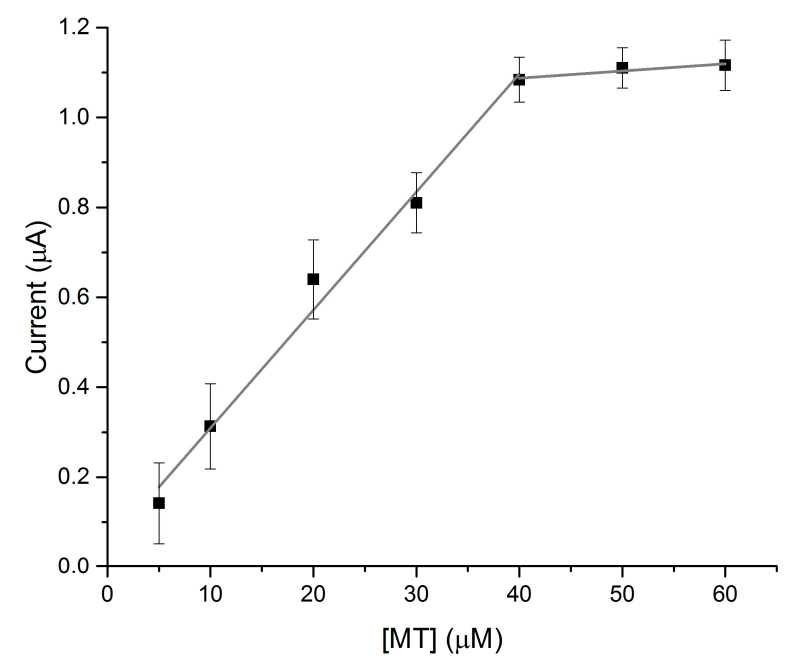

Figure 2. Influence of paper disc MT-loading on the peak heights of the $\mathrm{S}_{\mathrm{Cys}}$ responses at $+0.22 \mathrm{~V}$ in the electrochemical scans. The MT concentrations of each of the $20 \mu \mathrm{L}$ aliquots added to the paper discs are plotted on the x-axis $(n=3)$.

The blank discs on the SPCEs did not show any signals in the scans performed (Figure 3). The MT-adsorbed discs gave signals slightly above $+200 \mathrm{mV}$ in both ASV and CV scans, likely due to the presence of free thiols in the protein. There was also a reduction peak around $-50 \mathrm{mV}$ in the $\mathrm{CV}$ scan which corresponds to the cysteinyl thiols in MT. The heights of the peaks are relatively small and this is due to the presence of $\mathrm{Zn} / \mathrm{Cd}$ in the isolated, lyophilized protein masking the thiol signal. The presence of these bound metals is essential to the stability of the protein for longer periods of storage, as apo-MT degrades more rapidly and is prone to oxidation [38]. Compared to apo-MT, $\mathrm{Cd} / \mathrm{Zn}-\mathrm{MT}$ can be stored as a frozen solution or lyophilized and reconstituted after many years of storage without significant degradation. 


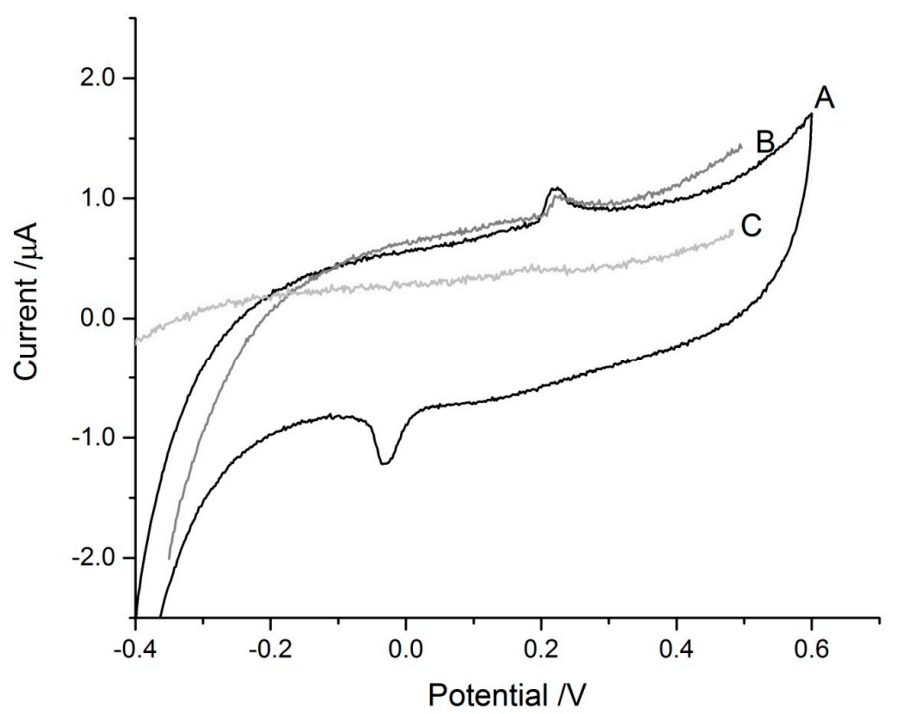

Figure 3. Representative electrochemical measurements of MT-loaded and blank-paper discs on SPCEs with $25 \mu \mathrm{L}$ of deionized water added. (A) Cyclic voltammetry (CV) scan of MT-adsorbed disc; (B) anodic stripping voltammetry (ASV) scan on MT-adsorbed disc; and (C) ASV scan of blank paper disc. The ASV and CV scans of the blank paper disc were similar and showed no distinct peaks.

\subsection{Arsenic Detection Using ASV}

The paper discs on the SPCE connected to the DropSens device, coupled with the eChem software was able to detect $\mathrm{As}^{3+}$ reasonably well in the control experiments, achieving a strong signal down to a concentration of $100 \mathrm{ppb}$. The limit of detection (LOD) (3S/N) calculated for the control paper disc on the SPCE was $69 \mathrm{ppb}$. For reference, the WHO recommended limit for arsenic in drinking water is $10 \mathrm{ppb}$. When the MT was physically adsorbed on to the paper discs placed over the SPCEs, the sensitivity was increased and the signal intensity amplified greatly. This can be seen in Figures 4 and 5, where the MT disc achieved a three-fold signal enhancement, which results in a detection limit below $20 \mathrm{ppb} \mathrm{As}{ }^{3+}$. LOD $(3 \mathrm{~S} / \mathrm{N})$ was calculated to be $13 \mathrm{ppb}$ for the MT-adsorbed discs on the SPCEs. While this is still higher than the WHO recommended limit for drinking water, it is low enough to potentially be useful in screening for arsenic contamination in high risk areas. For example, the Cambodian recommended limit is $50 \mathrm{ppb}$ with some wells having concentrations as high as $3.5 \mathrm{ppm}$ (to emphasize the danger, $3500 \mathrm{ppb}$ ) [39]. In Bangladesh, $43 \%$ of wells have concentrations exceeding $50 \mathrm{ppb}$ [17]. The incorporation of the cysteine-rich metallothionein pushed the LOD to concentrations below that typically found in areas of concern.

In addition to an increase in signal intensity, the interactions between the arsenic and MT-disc shifted the peak intensity to a more negative potential. The control disc with no MT adsorbed showed $\mathrm{As}^{3+}$-dependent peaks at approximately $+160 \mathrm{mV}$ (Figure 4 ) which is very similar to that reported in the literature with more sensitive electrodes [40-42]. The potential of $\mathrm{As}^{3+}$-stripping in the MT-modified disc scans was shifted to approximately $-60 \mathrm{mV}$ and this type of shift is consistent with coordination by thiol [43] and protein modified electrodes [44]. Both the control and experimental traces had high degrees of linearity over the range tested (Table 1). 


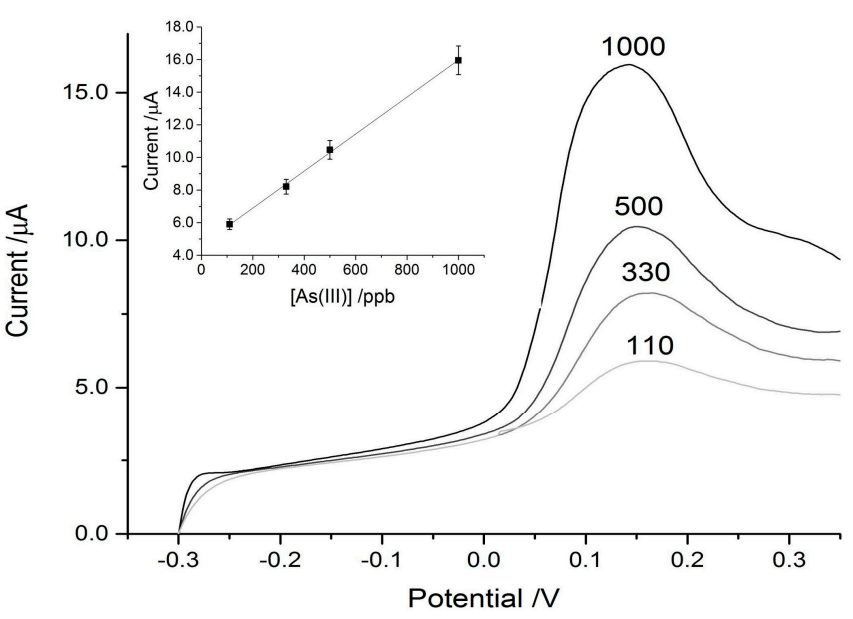

Figure 4. Typical ASV scans using blank paper discs on screen-printed carbon electrodes (SPCEs) with $25 \mu \mathrm{L}$ of arsenic solutions of varying concentration added. The arsenic concentrations are indicated above their respective trace. Inset in the top left is the linear response curve for the blank disc set-up.

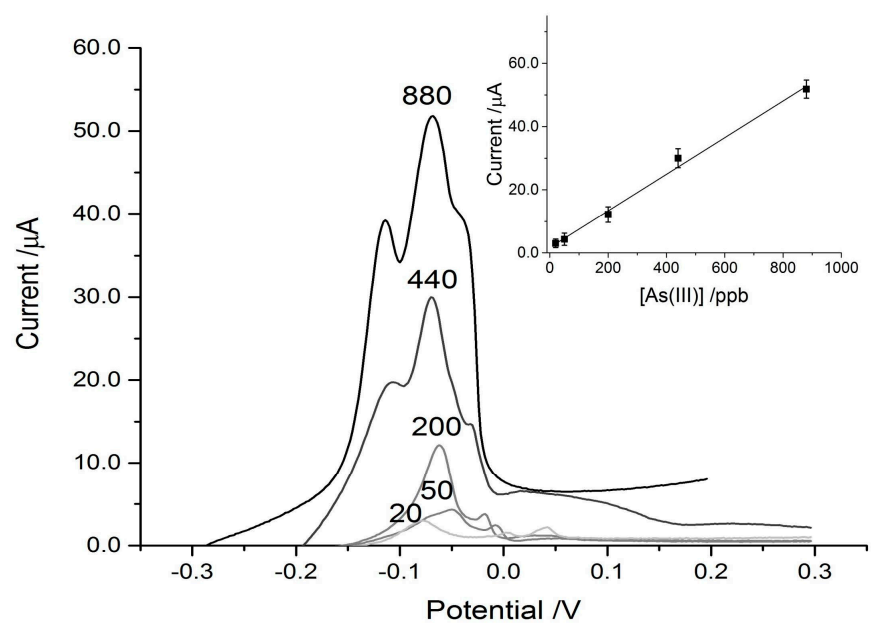

Figure 5. Representative ASV scans of MT-adsorbed paper discs with $25 \mu \mathrm{L}$ droplets of varying arsenic concentrations added. The concentrations are labeled above their respective traces. Inset in the top right is the linear response curve for the MT-disc set-up.

Table 1. Equation of linear regressions for $\mathrm{As}^{3+}$ and $\mathrm{Hg}^{2+}$ determinations.

\begin{tabular}{ccc}
\hline Experiment & Linear Regression Equation & $\mathbf{R}^{\mathbf{2}}$ \\
\hline $\mathrm{As}^{3+}$ control & $\mathrm{y}=1.135 \times 10^{-8}(\mathrm{x})+4.621 \times 10^{-6}$ & 0.9977 \\
$\mathrm{As}^{3+}$ MT-discs & $\mathrm{y}=5.999 \times 10^{-8}(\mathrm{x})+1.425 \times 10^{-6}$ & 0.9860 \\
$\mathrm{Hg}^{2+}$ control & $\mathrm{y}=5.494 \times 10^{-10}(\mathrm{x})+1.755 \times 10^{-7}$ & 0.9843 \\
$\mathrm{Hg}^{2+}$ MT-dics & $\mathrm{y}=2.545 \times 10^{-9}(\mathrm{x})+2.132 \times 10^{-7}$ & 0.9993 \\
\hline
\end{tabular}

\subsection{Mercury Detection Using ASV}

In addition to $\mathrm{As}^{3+}$, which selectively binds to $\mathrm{MT}$ at low $\mathrm{pH}$, we sought to leverage the higher affinity that MT generally has for $\mathrm{Hg}^{2+}$ over $\mathrm{Zn}^{2+}$ and $\mathrm{Cd}^{2+}$, as similar strategies have been previously tested for MT-based metal detection [45]. Since the affinity for $\mathrm{Hg}^{2+}$ is higher than that of the native metals bound to $\mathrm{MT}, \mathrm{Hg}^{2+}$ will displace these metals [46]. In addition, both zinc and cadmium require more negative plating potentials than were applied during this experiment, limiting their interference in this device. Upon lowering the $\mathrm{pH}$ for arsenic detection or the displacement by mercury, the interferent $(\mathrm{Cd} / \mathrm{Zn})$ concentration is approximately $280 \mu \mathrm{M}$. 
Below $20 \mathrm{ppb}$ detection of $\mathrm{Hg}^{2+}$ became impossible even with the enhancement from the MT-adsorbed discs. A comparison of Figures 6 and 7 show the approximately three-fold enhancement of the peak current achieved by the MT-disc. The WHO guideline upper limit for mercury in drinking water is six parts per billion, meaning the device is not achieving the sensitivity required to detect such low concentrations, especially in more natural samples with organic interferents. However, it may be more useful in monitoring area suspected of contamination which typically have higher concentrations that the recommended limit [47]. The LOD (3S/N) for the MT-modified paper disc was 45 ppb and $120 \mathrm{ppb}$ for the blank paper disc.

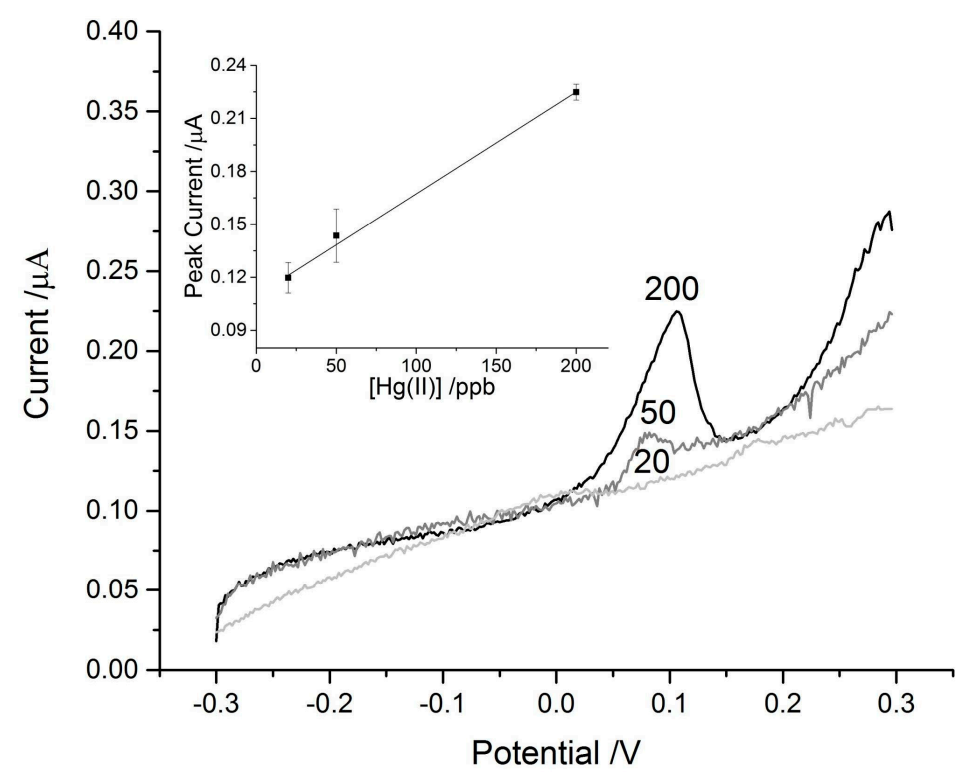

Figure 6. Representative ASV scans of blank paper discs on SPCEs with $25 \mu \mathrm{L}$ aliquots of $\mathrm{Hg}^{2+}$ solutions of concentrations 20,50 and $200 \mathrm{ppb}$. The concentration corresponding to each trace is labeled near the peaks at $+0.1 \mathrm{~V}$. Inset in the top left corner is the linear fit of the control data $(n=3)$.

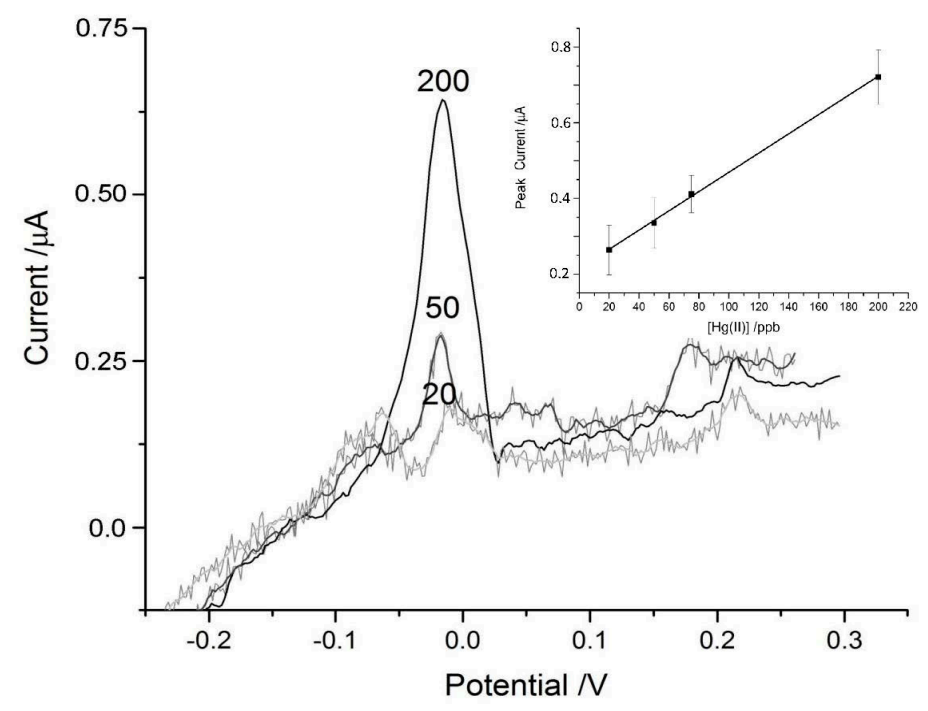

Figure 7. Representative ASV scans for MT-loaded discs with $25 \mu \mathrm{L}$ drops of diluted $\mathrm{Hg}^{2+}$ standards with concentrations of 20,50 and $200 \mathrm{ppb}$. The concentration is indicated on the graph near the $\mathrm{Hg}^{2+}$ peaks around $-0.02 \mathrm{~V}$. The peaks near $+0.2 \mathrm{~V}$ correspond to the thiols of metallothionein. Inset in the top right corner is the linear fit of the data $(n=3)$. 
The peak current for the $\mathrm{Hg}^{2+}$ signals was shifted to a more negative potential (Figure 7) similar to the shift in the $\mathrm{As}^{3+}$ signal seen in Figures 4 and 5. The peak seen around $+200 \mathrm{mV}$ in the experimental trace is from the thiols in the protein and was also observed in the control tests where deionized water was added to the MT-discs (Figure 3).

The linearity over the range of mercury concentrations typically found in water contaminated by industry is adequate since even polluted waters have concentrations up to $200 \mathrm{ppb}$ [47-49]. While the sensitivity of the device is not ideal for sensing lower concentrations of $\mathrm{Hg}^{2+}$ typical of non-industrially polluted waters, we have demonstrated the versatility in our approach in incorporating a protein known to interact with many soft metals and metalloids that cause environmental health problems. MT is able to enhance the signal of both metals tested due to its promiscuity of metal binding and lack of discriminatory metal binding sites.

The potential of MT-incorporated devices for sensing a wide range of metals is summarized in Table 2, which lists examples of various metallothioneins being used to enhance detection methods. The advantage of this strategy is that MT can enhance methods with specific advantages such as specificity, low detection limit, portability or low-cost. In our paper disc/SPCE sensor, we enhance a 'green' paper matrix with MT to produce a more sensitive $\mathrm{As}^{3+} / \mathrm{Hg}^{2+}$ sensor. The low-cost and environmentally friendly design of the sensor is greatly enhanced with the protein modification because the detection limit pre-MT adsorption is much higher than what would be considered acceptable.

Table 2. Summary of MT-incorporated biosensors.

\begin{tabular}{|c|c|c|c|c|}
\hline Metal & Method/Electrode Type & Modifiers and Extra Components & Detection Limit & Reference \\
\hline $\mathrm{Cd}, \mathrm{Zn}$ & HDME & TCEP & $5.6 \mathrm{ppb}$ & [41] \\
\hline $\mathrm{Cd}$ & Fluorescence & Zn-Chelex resin, Rh-labelled MT & $50 \mathrm{ppb}$ & {$[36]$} \\
\hline $\mathrm{Pt}$ (cisplatin) & HDME & TCEP & $10 \mathrm{ppb}$ & [23] \\
\hline $\mathrm{Ag}$ & Carbon paste & anti MT-antibodies & $0.05 \mathrm{ppb}$ & [25] \\
\hline Pd & HDME & TCEP & $10 \mathrm{ppb}$ & [42] \\
\hline As & Paper disc/SPCE & MT-adsorption & $13 \mathrm{ppb}$ & This work \\
\hline
\end{tabular}

By modifying the conditions under which the ASV scans are run, we can use MT as an effective and selective pre-concentration agent for both $\mathrm{As}^{3+}$ and $\mathrm{Hg}^{2+}$. Thus, the same device could be used for different assays depending on the type of contamination suspected in the given area. Table 2 shows a summary of the different metals sensed by a number of MT-based biosensors. It is likely a simple MT biosensor would be able to measure all the metals listed in Table 2, but slightly different strategies or configurations might have to be used. By using different MT isoforms [50] or a rational design approach [51,52] to increase the binding affinity for certain metals, a device could be customized for any soft metal. Another strategy would be to incorporate apo-MT to eliminate the need for the sensed metal to have a much higher affinity than the endogenous metals $(\mathrm{Cd} / \mathrm{Zn})$. This would pose additional engineering constraints due to the high oxygen sensitivity of metal-free metallothionein and would require more extensive sample preparation to remove dissolved oxygen [53-55].

\section{Conclusions}

Adsorbing the cysteine-rich protein metallothionein on to paper discs provided a simple, specific, sensitive and inexpensive sensor for the toxic metals $\mathrm{As}^{3+}$ and $\mathrm{Hg}^{2+}$. Metallothionein incorporation allowed the SPCE/paper disc system to sense $\mathrm{As}^{3+}$ at low enough concentrations to be potentially useful in environmental monitoring. This signal enhancement is likely due to pre-concentration effects of the MT-metal coordination. Our work shows that even simple physical adsorption of the protein onto an inexpensive SPCE/paper disc can dramatically increase the signal associated with a metal of interest without the need for costly coupling reagents or expensive and complicated set-ups. 
Acknowledgments: G.W.I. acknowledges financial support from NSERC of Canada through a CGS-D scholarship and a Michael Smith Foreign Study Supplement travel award to allow work at Nanyang Technological University-National Institute of Education, Singapore. G.W.I. also acknowledges the support of SNT and Nadia Sekar of NTU-NIE for their helpful expertise in the field of electrochemistry and biosensors and Kim Irvine also of NTU-NIE for his insight on the environmental and social impacts of $\mathrm{As}^{3+}$ contamination to help put this work into context. M.J.S. acknowledges financial support from NSERC of Canada through a Discovery grant (37-2015).

Author Contributions: G.W.I. and S.N.T. conceived of and designed the experiments; G.W.I. performed the experiments; G.W.I., M.J.S. and S.N.T. analyzed the data; S.N.T and M.J.S. contributed reagents/materials/analysis tools; G.W.I. and M.J.S. wrote the paper with significant input and editing from S.N.T.

Conflicts of Interest: The authors declare no conflict of interest.

\section{References}

1. Phan, K.; Phan, S.; Heng, S.; Huoy, L.; Kim, K.-W. Assessing Arsenic Intake from Groundwater and Rice by Residents in Prey Veng Province, Cambodia. Environ. Pollut. 2014, 185, 84-89. [CrossRef] [PubMed]

2. Wasserman, G.A.; Liu, X.; Lolacono, N.J.; Kline, J.; Factor-Litvak, P.; van Geen, A.; Mey, J.L.; Levy, D.; Abramson, R.; Schwartz, A. A Cross-Sectional Study of Well Water Arsenic and Child IQ in Maine Schoolchildren. Environ. Health 2014, 13, 1. [CrossRef] [PubMed]

3. Kudo, A.; Miyahara, S. A Case History; Minamata Mercury Pollution in Japan-from Loss of Human Lives to Decontamination. Water Sci. Technol. 1991, 23, 283-290.

4. Wang, Q.; Kim, D.; Dionysiou, D.D.; Sorial, G.A.; Timberlake, D. Sources and Remediation for Mercury Contamination in Aquatic Systems-A Literature Review. Environ. Pollut. 2004, 131, 323-336. [CrossRef] [PubMed]

5. Loux, N.T. An Assessment of Mercury-Species-Dependent Binding with Natural Organic Carbon. Chem. Speciat. Bioavailab. 1998, 10, 127-136. [CrossRef]

6. Lu, W.; Stillman, M.J. Mercury-Thiolate Clusters in Metallothionein. Analysis of Circular Dichroism Spectra of Complexes Formed Between. Alpha.-Metallothionein, Apometallothionein, Zinc Metallothionein, and Cadmium Metallothionein and Mercury (2+). J. Am. Chem. Soc. 1993, 115, 3291-3299. [CrossRef]

7. Stillman, M.J.; Thomas, D.; Trevithick, C.; Guo, X.; Siu, M. Circular Dichroism, Kinetic and Mass Spectrometric Studies of Copper (I) and Mercury (II) Binding to Metallothionein. J. Inorg. Biochem. 2000, 79, 11-19. [CrossRef]

8. Chen, R.W.; Ganther, H.E.; Hoekstra, W.G. Studies on the Binding of Methylmercury by Thionein. Biochem. Biophys. Res. Commun. 1973, 51, 383-390. [CrossRef]

9. Piotrowski, J.K.; Trojanowska, B.; Wiśniewska-Knypl, J.M.; Bolanowska, W. Mercury Binding in the Kidney and Liver of Rats Repeatedly Exposed to Mercuric Chloride: Induction of Metallothionein by Mercury and Cadmium. Toxicol. Appl. Pharmacol. 1974, 27, 11-19. [CrossRef]

10. Irvine, G.W.; Duncan, K.E.R.; Gullons, M.; Stillman, M.J. Metalation Kinetics of the Human A-Metallothionein 1a Fragment Is Dependent on the Fluxional Structure of the Apo-Protein. Chemistry 2015, 21, 1269-1279. [CrossRef] [PubMed]

11. Chen, S.-H.; Chen, L.; Russell, D.H. Metal-Induced Conformational Changes of Human Metallothionein-2a: A Combined Theoretical and Experimental Study of Metal-Free and Partially Metalated Intermediates. J. Am. Chem. Soc. 2014, 136, 9499-9508. [CrossRef] [PubMed]

12. Polya, D.A.; Gault, A.G.; Bourne, N.J.; Lythgoe, P.R.; Cooke, D.A. Coupled Hplc-Icp-Ms Analysis Indicates Highly Hazardous Concentrations of Dissolved Arsenic Species in Cambodian Groundwaters. Plasma Source Mass Spectrom. 2003, 288, 127-140.

13. Duan, G.; Liu, W.; Chen, X.; Hu, Y.; Zhu, Y. Association of Arsenic with Nutrient Elements in Rice Plants. Metallomics 2013, 5, 784-792. [CrossRef] [PubMed]

14. Murphy, T.; Sampson, M.; Le, C.; Irvine, K.; Gerads, R.; Smith, L.; Parr, T.; Irvine, K.; Murphy, T.; Vermette, S. Arsenic Bioaccumulation in an Arsenic Rich Area of Cambodia. Water Resour. Dev. Southeast Asia 2010, 1, $57-88$.

15. Berg, M.; Stengel, C.; Trang, P.T.K.; Viet, P.H.; Sampson, M.L.; Leng, M.; Samreth, S.; Fredericks, D. Magnitude of Arsenic Pollution in the Mekong and Red River Deltas-Cambodia and Vietnam. Sci. Total Environ. 2007, 372, 413-425. [CrossRef] [PubMed] 
16. Sampson, M.L.; Bostick, B.; Chiew, H.; Hagan, J.M.; Shantz, A. Arsenicosis in Cambodia: Case Studies and Policy Response. Appl. Geochem. 2008, 23, 2977-2986. [CrossRef]

17. Smith, A.H.; Lingas, E.O.; Rahman, M. Contamination of Drinking-Water by Arsenic in Bangladesh: A Public Health Emergency. Bull. World Health Organ. 2000, 78, 1093-1103. [PubMed]

18. Mitra, A.K.; Bose, B.K.; Kabir, H.; Das, B.K.; Hussain, M. Arsenic-Related Health Problems among Hospital Patients in Southern Bangladesh. J. Health Popul. Nutr. 2002, 20, 198-204. [PubMed]

19. Babkina, S.S.; Ulakhovich, N.A. Complexing of Heavy Metals with DNA and New Bioaffinity Method of Their Determination Based on Amperometric DNA-Based Biosensor. Anal. Chem. 2005, 77, 5678-5685. [CrossRef] [PubMed]

20. Verma, N.; Singh, M. Biosensors for Heavy Metals. BioMetals 2005, 18, 121-129. [CrossRef] [PubMed]

21. Wiśniewska, J.M.; Trojanowska, B.; Piotrowski, J.; Jakubowski, M. Binding of Mercury in the Rat Kidney by Metallothionein. Toxicol. Appl. Pharmacol. 1970, 16, 754-763. [CrossRef]

22. Waalkes, M.P.; Harvey, M.J.; Klaassen, C.D. Relative in Vitro Affinity of Hepatic Metallothionein for Metals. Toxicol. Lett. 1984, 20, 33-39. [CrossRef]

23. Funk, A.E.; FDay, A.; Brady, F.O. Displacement of Zinc and Copper from Copper-Induced Metallothionein by Cadmium and by Mercury: In Vivo and Ex Vivo Studies. Comp. Biochem. Physiol. Part C Comp. Pharmacol. 1987, 86, 1-6. [CrossRef]

24. Xu, M.; Yang, L.; Wang, Q. Chemical Interactions of Mercury Species and Some Transition and Noble Metals Towards Metallothionein (Zn 7 Mt-2) Evaluated Using Sec/Icp-Ms, Rp-Hplc/Esi-Ms and Maldi-Tof-Ms. Metallomics 2013, 5, 855-860. [CrossRef] [PubMed]

25. Cai, W.; Stillman, M.J. (Mercury) 18-Metallothionein. J. Am. Chem. Soc. 1988, 110, 7872-7873. [CrossRef]

26. Ngu, T.T.; Easton, A.; Stillman, M.J. Kinetic Analysis of Arsenic-Metalation of Human Metallothionein: Significance of the Two-Domain Structure. J. Am. Chem. Soc. 2008, 130, 17016-17028. [CrossRef] [PubMed]

27. Irvine, G.W.; Stillman, M.J. Topographical Analysis of as-Induced Folding of A-Mt1a. Biochem. Biophys. Res. Commun. 2013, 441, 208-213. [CrossRef] [PubMed]

28. Freisinger, E.; Milan, V. Cadmium in Metallothioneins. In Cadmium: From Toxicity to Essentiality; Springer: Berlin, Germany, 2013; pp. 339-371.

29. Jiang, G.; Gong, Z.; Li, X.-F.; Cullen, W.R.; Le, X.C. Interaction of Trivalent Arsenicals with Metallothionein. Chem. Res. Toxicol. 2003, 16, 873-880. [CrossRef] [PubMed]

30. Wu, C.-M.; Lin, L.-Y. Immobilization of Metallothionein as a Sensitive Biosensor Chip for the Detection of Metal Ions by Surface Plasmon Resonance. Biosens. Bioelectr. 2004, 20, 864-871. [CrossRef] [PubMed]

31. Amaro, F.; Turkewitz, A.P.; Martín-González, A.; Gutiérrez, J.-C. Whole-Cell Biosensors for Detection of Heavy Metal Ions in Environmental Samples Based on Metallothionein Promoters from Tetrahymena Thermophila. Microb. Biotechnol. 2011, 4, 513-522. [CrossRef] [PubMed]

32. Petrlova, J.; Potesil, D.; Zehnalek, J.; Sures, B.; Adam, V.; Trnkova, L.; Kizek, R. Cisplatin Electrochemical Biosensor. Electrochim. Acta 2006, 51, 5169-5173. [CrossRef]

33. Hu, S.; Ye, B.; Yi, X.; Cao, Z.; Wu, D.; Shen, C.; Wang, J. Dumbbell-Shaped Metallothionein-Templated Silver Nanoclusters with Applications in Cell Imaging and $\mathrm{Hg}^{2+}$ Sensing. Talanta 2016, 155, 272-277. [CrossRef] [PubMed]

34. Trnkova, L.; Krizkova, S.; Adam, V.; Hubalek, J.; Kizek, R. Immobilization of Metallothionein to Carbon Paste Electrode Surface Via Anti-Mt Antibodies and Its Use for Biosensing of Silver. Biosens. Bioelectr. 2011, 26, 2201-2207. [CrossRef] [PubMed]

35. Krizkova, S.; Huska, D.; Beklova, M.; Hubalek, J.; Adam, V.; Trnkova, L.; Kizek, R. Protein-Based Electrochemical Biosensor for Detection of Silver (I) Ions. Environ. Toxicol. Chem. 2010, 29, 492-496. [CrossRef] [PubMed]

36. Chan, J.; Huang, Z.; Watt, I.; Kille, P.; Stillman, M.J. Characterization of the Conformational Changes in Recombinant Human Metallothioneins Using Esi-Ms and Molecular Modeling. Can. J. Chem. 2007, 85, 898-912. [CrossRef]

37. Sekar, N.C.; Ge, L.; Shaegh, S.A.M.; Ng, S.H.; Tan, S.N. A Mediated Turnip Tissue Paper-Based Amperometric Hydrogen Peroxide Biosensor. Sens. Actuators B Chem. 2015, 210, 336-342. [CrossRef]

38. Klaassen, C.D.; Choudhuri, S.; McKim, J.M., Jr.; Lehman-McKeeman, L.D.; Kershaw, W.C. In Vitro and in Vivo Studies on the Degradation of Metallothionein. Environ. Health Perspect. 1994, 102 (Suppl. 3), 141. [CrossRef] 
39. Polya, D.A.; Berg, M.; Gault, A.G.; Takahashi, Y. Arsenic in Groundwaters of South-East Asia: With Emphasis on Cambodia and Vietnam. Appl. Geochem. 2008, 23, 2968-2976. [CrossRef]

40. Kopanica, M.; Novotný, L. Determination of Traces of Arsenic (III) by Anodic Stripping Voltammetry in Solutions, Natural Waters and Biological Material. Anal. Chim. Acta 1998, 368, 211-218. [CrossRef]

41. Xiao, L.; Wildgoose, G.G.; Compton, R.G. Sensitive Electrochemical Detection of Arsenic (III) Using Gold Nanoparticle Modified Carbon Nanotubes Via Anodic Stripping Voltammetry. Anal. Chim. Acta 2008, 620, 44-49. [CrossRef] [PubMed]

42. Dai, X.; Nekrassova, O.; Hyde, M.E.; Compton, R.G. Anodic Stripping Voltammetry of Arsenic (III) Using Gold Nanoparticle-Modified Electrodes. Anal. Chem. 2004, 76, 5924-5929. [CrossRef] [PubMed]

43. Li, D.; Li, J.; Jia, X.; Han, Y.; Wang, E. Electrochemical Determination of Arsenic (III) on Mercaptoethylamine Modified Au Electrode in Neutral Media. Anal. Chim. Acta 2012, 733, 23-27. [CrossRef] [PubMed]

44. Fuku, X.; Iftikar, F.; Hess, E.; Iwuoha, E.; Baker, P. Cytochrome C Biosensor for Determination of Trace Levels of Cyanide and Arsenic Compounds. Anal. Chim. Acta 2012, 730, 49-59. [CrossRef] [PubMed]

45. Varriale, A.; Staiano, M.; Rossi, M.; D'Auria, S. High-Affinity Binding of Cadmium Ions by Mouse Metallothionein Prompting the Design of a Reversed-Displacement Protein-Based Fluorescence Biosensor for Cadmium Detection. Anal. Chem. 2007, 79, 5760-5762. [CrossRef] [PubMed]

46. Leiva-Presa, À.; Capdevila, M.; Gonzàlez-Duarte, P. Mercury (II) Binding to Metallothioneins. Eur. J. Biochem. 2004, 271, 4872-4880. [CrossRef] [PubMed]

47. Li, P.; Feng, X.B.; Qiu, G.L.; Shang, L.H.; Li, Z.G. Mercury Pollution in Asia: A Review of the Contaminated Sites. J. Hazard. Mater. 2009, 168, 591-601. [CrossRef] [PubMed]

48. Zhang, G.; Liu, C.-Q.; Wu, P.; Yang, Y. The Geochemical Characteristics of Mine-Waste Calcines and Runoff from the Wanshan Mercury Mine, Guizhou, China. Appl. Geochem. 2004, 19, 1735-1744. [CrossRef]

49. Feng, X.; Dai, Q.; Qiu, G.; Li, G.; He, L.; Wang, D. Gold Mining Related Mercury Contamination in Tongguan, Shaanxi Province, Pr China. Appl. Geochem. 2006, 21, 1955-1968. [CrossRef]

50. Bofill, R.; Orihuela, R.; Romagosa, M.; Domenech, J.; Atrian, S.; Capdevila, M. Caenorhabditis Elegans Metallothionein Isoform Specificity-Metal Binding Abilities and the Role of Histidine in Cemt1 and Cemt2. FEBS J. 2009, 276, 7040-7056. [CrossRef] [PubMed]

51. Mocny, C.S.; Pecoraro, V.L. De Novo Protein Design as a Methodology for Synthetic Bioinorganic Chemistry. Acc. Chem. Res. 2015, 48, 2388-2396. [CrossRef] [PubMed]

52. Zhou, L.; Bosscher, M.; Zhang, C.; Özçubukçu, S.; Zhang, L.; Zhang, W.; Li, C.J.; Liu, J.; Jensen, M.P.; Lai, L. A Protein Engineered to Bind Uranyl Selectively and with Femtomolar Affinity. Nat. Chem. 2014, 6, $236-241$. [CrossRef] [PubMed]

53. Maret, W. Oxidative Metal Release from Metallothionein Via Zinc-Thiol/Disulfide Interchange. Proc. Natl. Acad. Sci. USA 1994, 91, 237-241. [CrossRef] [PubMed]

54. Minkel, D.T.; Poulsen, K.; Wielgus, S.; Shaw, C.F.; Petering, D.H. On the Sensitivity of Metallothioneins to Oxidation During Isolation. Biochem. J. 1980, 191, 475-485. [CrossRef] [PubMed]

55. Kassim, R.; Ramseyer, C.; Enescu, M. Oxidation Reactivity of Zinc-Cysteine Clusters in Metallothionein. J. Biol. Inorg. Chem. 2013, 18, 333-342. [CrossRef] [PubMed]

(C) 2017 by the authors. Licensee MDPI, Basel, Switzerland. This article is an open access article distributed under the terms and conditions of the Creative Commons Attribution (CC BY) license (http:/ / creativecommons.org/licenses/by/4.0/). 